JKTP Vol 3 No (4) November (2020): 350-365

JKTP Jurnal Kajian Teknologi Pendidikan

DOI:10.17977/um038v3i42020p350

http://journal2.um.ac.id/index.php/jktp/index

\title{
MEMBUDAYAKAN KELAS DIGITAL UNTUK MEMBIMBING SISWA DALAM PEMBELAJARAN DI TENGAH PANDEMI COVID-19
}

\author{
Reni Kurniawati Pertiwi, Sutama \\ Program Studi Pendidikan Matematika, Universitas Muhammadiyah Surakarta \\ Email: renikurniawati747@gmail.com,sutama@ums.ac.id
}

\begin{tabular}{|c|c|}
\hline Article History & Abstrak \\
\hline $\begin{array}{l}\text { Received: 02-07-2020 } \\
\text { Accepted: 08-08-2020 } \\
\text { Published: } 30-11-2020\end{array}$ & $\begin{array}{l}\text { Sejak merebaknya pandemi Coronavirus Disease (Covid-19) memberikan } \\
\text { pengaruh signifikan pada aspek kehidupan terutama pendidikan. Dalam } \\
\text { pembelajaran digital masih belum terealisasi dengan baik sehingga perlu } \\
\text { adanya pembiasaan sehingga pembelajaran dapat tercapai selaras dengan tujuan } \\
\text { yang ingin dicapai. Tujuan dari penulisan artikel ini yaitu 1) Mendeskripsikan } \\
\text { kelas digital untuk membimbing siswa dalam pembelajaran di tengah pandemi } \\
\text { Covid-19; 2) Menganalisis pembudayaan kelas digital untuk membimbing } \\
\text { siswa dalam pembelajaran di tengah pandemi Covid-19. Metode penelitian } \\
\text { menggunakan kajian pustaka. Fokus penelitian yaitu pembudayaan } \\
\text { pembelajaran kelas digital. Keabsahan data dilakukan dengan triangulasi } \\
\text { perpanjangan waktu. Teknik analisis data menggunakan komparasi konstan. } \\
\text { Hasil penelitian ini yaitu dapat membiasakan dan membudayakan kelas digital } \\
\text { sebagai salah satu pembelajaran daring di tengah pandemi Covid-19. } \\
\text { Abstract }\end{array}$ \\
\hline & $\begin{array}{l}\text { Since the outbreak of the pandemic Coronavirus Disease (Covid-19) has had a } \\
\text { significant influence on aspects of life, especially education. Digital learning is } \\
\text { still not well realized, so there is a need for habituation so that learning can be } \\
\text { achieved in line with the objectives to be achieved. The purpose of writing this } \\
\text { article are 1) Describe the digital class to guide students in learning in the } \\
\text { midst of the Covid-19 pandemic; 2) Analyzing the culture of digital classrooms } \\
\text { to guide students in learning in the midst of the Covid-19 pandemic. The } \\
\text { research method uses literature review. The focus of research is the } \\
\text { acculturation of digital classroom learning. Data validity is done by extending } \\
\text { triangulation. The data analysis technique uses constant comparison. The } \\
\text { results of this study are able to familiarize and civilize digital classrooms as } \\
\text { one of online learning in the middle of the Covid-19 pandemic. }\end{array}$ \\
\hline
\end{tabular}




\section{PENDAHULUAN}

Sejak menyebarnya pandemi Covid-19, pemerintah melakukan berbagai upaya untuk preventif penularan Covid-19. Salah satunya melalui Surat Edaran No 1 Tahun 2020 Tentang Pencegahan Penyebaran Coronavirus Disease (Covid-19). Dari surat edaran yang dikeluarkan oleh pemerintah tersebut, Kemendikbud menyarankan untuk pembelajaran jarak jauh dan belajar dari rumah. Sehingga para siswa dan guru mengikuti anjuran tersebut guna menekan penyebaran Covid-19. Sebagai upaya dalam preventif penyebaran Covid-19, WHO merekomendasikan untuk membubarkan sementara kegiatan-kegiatan yang berpotensi memicu kerumunan massa (Firman \& Rahayu, 2020). Supaya siswa tetap belajar dirumah, Kemendikbud mengembangkan aplikasi pembelajaran jarak jauh yaitu Portal Rumah Belajar bisa diakses melalui website leaning.kemendikbud.go.id (Kemendikbud, 2020).

Menurut Purnomo (2020) yang termuat dalam Pikiran Rakyat, pemberian penugasan kepada siswa dipandang efektif dalam pembelajaran jarak jauh dalam masa darurat yang disebabkan adanya Covid-19 namun untuk pemahaman konsep sampai dengan refleksi tidak berjalan dengan baik (Ashari, 2020). Akar penyebab dari permasalahan dalam pembelajaran daring disebabkan karena kurangnya guru dalam memahami konsep seperti apa pembelajaran daring, sebagian besar guru kurang update mengenai pembelajaran daring ini dengan menggunakan platform-platform yang telah tersedia serta terhambatnya koneksi internet bagi kota terpencil. Sehingga perlu diadakannya pembiasaan dan pembudayaan kelas digital agar sesuai dengan harapan pada revolusi industri 4.0. Pembiasaan dan pembudayaan juga bertujuan agar siswa dapat memiliki wawasan mengenai revolusi industri 5.0 yang sudah menerapkan sepenuhnya kelas digital yang merupakan lanjutan dari revolusi industri 4.0. Hal ini disebabkan pada perubahan dunia memasuki revolusi industri 4.0 dimana teknologi menjadi pondasi dalam kehidupan manusia (Subekti et al., 2017).

Revolusi industri 4.0 mengubah dunia, yang pertama yaitu mekanik dan tenaga air, yang kedua menjadi era ilmu pengetahuan, dan yang ketiga yaitu teknologi (Fomunyam, 2019). Menurut Aziz, H \& Gamar et al., (dalam Fitriyani et al., 2020) menyatakan perkembangan teknologi menjadi sebuah daya kapasitas dalam berbagai bidang terkhusus pada pendidikan sehingga harus terdapat reaksi yang positif dan adaptif dalam menjawab tantangan abad 21 pada revolusi industri 4.0 yang banyak komplikasi. Keberadaan teknologi dalam pendidikan dapat digunakan untuk mencanangkan strategi pembelajaran baik secara searah maupun interaktif (Husaini, 2014). Di bidang pendidikan, dalam kemajuan teknologi memungkinkan pembelajaran jarak jauh (daring) dan membangun inovasi yang lebih besar dalam pengajaran (Almeida \& Simoes, 2019). Transformasi digital dalam pendidikan di Indonesia bukanlah suatu wacana yang baru dari berbagai isu, regulasi pendukung dan upaya konkret menerapkan transformasi digital di lingkungan perguruan tinggi dan semua tingkat sekolah di Indonesia selama pandemic Covid-19 (Astini, 2020)

Salah satu solusi untuk pembelajaran yang dilakukan selama masa Work From Home (WFH) Covid-19 yaitu pembelajaran secara daring (jarak jauh) yang pada awalnya kegiatan belajar mengajar dilakukan di sekolah atau secara konvensional. Menurut Moore, Dickson-Deane, \& Galyen (dalam Firman \& Rahayu, 2020) pembelajaran daring merupakan suatu pembelajaran yang menggunakan internet dengan aksesibilitas, konektivitas, fleksibilitas, dan kemampuan untuk menyajikan bermacam jenis korelasi dalam pembelajaran. Saat ini berdasarkan informasi bahwa Kemendikbud bekerjasama dalam pengelolaan pembelajaran secara daring dilakukan dengan berbagai pihak yang mengembangkan sistem pendidikan yaitu Google Indonesia, Kelas Pintar, Microsoft, Quipper, Ruang Guru, Sekolahmu, dan Zenius. Pembelajaran daring (jarak jauh) sendiri memiliki tujuan untuk memenuhi tolak ukur pendidikan dengan penggunaan teknologi informasi 
dengan menggunakan peranti komputer atau gadget yang saling terhubung antara siswa dan guru sehingga melalui penggunaan teknologi tersebut proses belajar mengajar agar tetap dilaksanakan dengan baik dan efektif serta berjalan sebagaimana mestinya seperti pembelajaran pada umumnya (Pakpahan \& Fitriani, 2020).

Kelas digital (digital class) merupakan suatu teknologi pembelajaran dengan fasilitas aplikasi berbasis pada Learning Management System (LMS) maupun video conference. Learning Management System berupa platform portal e-learning baik yang tersedia oleh institusi pendidikan maupun dari pihak yang bekerjasama dengan Kemendikbud. Kelas digital adalah suatu kelas dengan memanfaatkan internet, multimedia dan teknologi sebagai sarana untuk kegiatan belajar mengajar secara daring (Rindia \& Firdausi, 2019). Kelas digital memungkinkan untuk belajar melalui internet masing-masing dengan penggunaan IT. Penggunaan IT dapat berupa komputer, laptop maupun gadget. Perkembangan IT memiliki banyak pengaruh dalam pendidikan. Menurut Rosenberg (dalam Wahyudin, 2010) berkembangnya dalam pemanfaatan teknologi terdapat lima perpindahan dalam proses pembelajaran, yaitu: 1) dari pelatihan ke penampilan, 2) dari ruang kelas ke ruang bebas baik waktu dan tempat, 3) dari kertas ke online atau saluran, 4) dari fasilitas fisik ke fasilitas jaringan kerja; 5) dari waktu siklus ke waktu nyata.

Dalam Surat Edaran Nomor 4 Tahun 2020 Tentang Pelaksanaan Kebijakan Pendidikan Dalam Masa Darurat Penyebaran Covid-19 yang memuat tentang belajar dari rumah yang melalui pembelajaran jarak jauh atau pembelajaran daring. Pada pembelajaran jarak jauh difokuskan bukan hanya akademik saja namun juga pada pembelajaran literasi, numerasi dan pendidikan karakter (Handayani, 2020). Pendidikan karakter bisa berupa kebiasaan-kebiasaan baru yang akhirnya menjadi budaya literasi kelas digital ini.

Dalam pembelajaran digital kedepannya menggunakan less paper, berpusat pada siswa (student centered), dipelajari secara mandiri, fokus terhadap proses pembelajarannya (Effendi, $\mathrm{H}$ \& Dwiyani, N, 2019) sehingga mampu bersaing di kancah global. Pembelajaran kelas digital membantu siswa memahami materi, pembelajaran menjadi lebih menyenangkan, memudahkan guru dalam penyampaian materi apabila guru melek teknologi, mengevaluasi hasil siswa sampai dengan memantau kehadiran siswa dalam pembelajaran. Penerapan sistem kelas digital dapat berupa, audio online, video online, tugas online, ujian online, nilai tugas dan nilai ujian online yang bisa ditujukan untuk orang tua, serta absensi digital dan sistem koreksi soal otomatis (Hartanto \& Nurhajanti, 2018).

Penelitian Abidah, A et al., (2020) membahas mengenai efek dari Covid-19 untuk pendidikan di Indonesia dan hubungannya dengan Merdeka Belajar. Dalam pembelajaran pada pandemi Covid-19 ini menerapkan sistem physical distancing dan social distancing sehingga menyebabkan yang pada awalnya pembelajaran tradisional menjadi pembelajaran digital dengan memanfaatkan penggunaan teknologi dengan maksimal. Meskipun dalam pembelajaran digital (jarak jauh) merupakan visi dan misi yang sesuai dengan revolusi 4.0 dan 5.0, namun belum berhasil secara maksimal dalam penggunaan teknologi.

Penelitian Latip, A (2020) yang membahas tentang literasi teknologi dalam Pembelajaran Jarak Jauh (PJJ) sebagai bentuk salah satu solusi pembelajaran dalam masa pandemi Covid-19. Dalam penggunaan teknologi mendorong pada peningkatan literasi teknologi yang menghasilkan kebiasaan-kebiasaan baru dalam proses pembelajaran yang selanjutnya. Sehingga kebiasaankebiasaan baru yang tertanam pada siswa menjadi budaya siswa dan guru untuk menerapkan kelas digital dalam proses pembelajaran.

Kedua penelitian terdahulu tersebut, terdapat kurangnya pemahaman dalam penerapan teknologi informasi dan komunikasi dalam pembelajaran jarak jauh serta kurangnya dalam 
pembiasaan teknologi informasi dan komunikasi sehingga siswa menjadi kesulitan dalam penggunaan teknologi pada pembelajaran. Sehingga penelitian ini bermaksud memberikan pemahaman tentang pentingnya membiasakan dan membudayakan kelas digital (jarak jauh) untuk membimbing siswa dalam pembelajaran di tengah pandemi Covid-19.

Dalam pembudayaan kelas digital diperlukan adanya strategi atau model yang perlu diterapkan dalam pembelajaran daring di masa pandemi Covid-19 agar dapat berjalan dengan baik dan efektif. Kelas digital ini siswa tidak hanya diberikan penugasan-penugasan yang membuat siswa bosan dan menjenuhkan, namun juga diberikan beberapa pelatihan diantaranya pelatihan wawasan kelas digital sehingga siswa, guru, dan orang tua memiliki wawasan yang lebih jauh mengenai kelas digital. Terdapat platform yang mampu mewadahi kelas digital yang berbasis Learning Management System sehingga Kemendikbud bekerjasama dengan berbagai pihak yang mengembangkan sistem pendidikan seperti Google Indonesia, Kelas Pintar, Microsoft, Quipper, Ruang Guru, Sekolahmu, dan Zenius serta Portal Rumah Belajar yang dimiliki oleh Kemendikbud.

Penelitian terdahulu yang dilakukan oleh Abidah, A (2020), Latip (2020) membahas mengenai kurangnya pemahaman penggunaan digital yang disebabkan belum menjadi suatu kebiasaan dalam pembelajaran digital dengan penggunaan teknologi. Penelitian yang dilakukan oleh penulis ini, membahas mengenai suatu pembiasaan dan pembudayaan teknologi yang harus diterapkan oleh semua para pendidik, dan siswa yang menjadi acuan dasar dalam pembelajaran daring (online) Dari uraian di atas, maka tujuan artikel ini yaitu (1) mendeskripsikan pembelajaran kelas digital (e-learning) untuk membimbing siswa dalam pembelajaran di tengah pandemi Covid19; (2) membudayakan kelas digital untuk membimbing siswa dalam pembelajaran di tengah pandemi Covid-19.

\section{METODE}

Jenis metode penelitian ini yaitu metode kajian pustaka. Metode kajian pustaka yaitu metode dengan mengintegrasikan teori-teori yang sudah ada, kemudian dijadikan referensi seperti artikel, jurnal, berita, skripsi, tesis, disertasi, handout.

Fokus penelitian yaitu pembudayaan pembelajaran kelas digital. Kelas digital adalah suatu kelas dalam pembelajaran dengan memanfaatkan teknologi sehingga bersifat efektif dan efisien. Kelas digital merupakan kelas dengan menghubungkan koneksi internet, sehingga materi, tugas, dan penilaian juga bersifat online (daring).

Menurut Sutama (2019:124), triangulasi sumber yaitu data diperoleh dengan sumber yang berbeda-beda dengan teknik yang sama. Keabsahan data dilakukan dengan triangulasi perpanjangan waktu. Triangulasi perpanjangan waktu yaitu data diperoleh dengan sumber yang berbeda-beda dengan waktu berulang-ulang sehingga diperoleh data yang sah (absah).

Teknik analisis data menggunakan komparasi konstan. Komparasi konstan yaitu membandingkan data dengan sumber-sumber yang telah ada yang dilakukan selama penelitian masih berlangsung dengan secara berulang-ulang. Teknik analisis data ini berupa pengumpulan data, reduksi data, penyajian data dan penarikan simpulan data.

Dalam kajian pustaka ini, terdapat 30 artikel jurnal yang terdiri dari 28 jurnal nasional dan 2 jurnal internasional. Penulis mencari seluruh artikel dari layanan Google Scholar dan data base artikel lainnya. Penulis menyeleksi semua artikel yang dipilih berdasarkan subjek riset, metode yang digunakan, ukuran sampel, wilayah konteks riset, dan waktu terbit. Hal itu sebagaimana yang kami jabarkan pada tabel 1. 
Tabel 1. Skema kajian pustaka penelitian

\begin{tabular}{lll}
\hline Dimensi & Sub-Dimensi & \\
\hline Subjek & Tingkat Sampel & (1) Sekolah Dasar, \\
& & (2) SMP dan SMA, \\
& & (3) Perguruan Tinggi; \\
& & (4) Lain-lain (umum) \\
& & (1) $1-30 ;(2)$ 30-60; (3) Lebih dari 60 \\
Aturan & (1) Studi Kasus \\
& (2) Studi Literatur Review \\
& Desain Penelitian & (3) Fenomenologi \\
& & (4) Pra-Eksperimental \\
& & (1) Singkat (<4 minggu) \\
& Durasi Intervensi & (2) Pendek (5-16 minggu) \\
& & (3) Menengah (17-24 minggu) \\
& & (4) Panjang (> 24 minggu) \\
Konteks & Wilayah Sampel & (1) Indonesia; \\
& & (2) Portugis \\
Alat & (3) Afrika \\
Tlat pembelajaran & (1) Platform pembelajaran online (daring) \\
& & (2) Lain-lain \\
& Tahun Terbit & (1) 2010-2015 \\
& & (2) 2016-2020
\end{tabular}

\section{HASIL}

Dari 30 jurnal yang menjadi rujukan literature review. Gambar 1 menyajikan distribusi publikasi ilmiah mengenai pembelajaran daring (online) dengan jangka waktu 5 tahun. Pada tahun 2010-2015 terdapat 2 jurnal, dan pada tahun 2016-2020 terdapat 28 jurnal. Hal ini menunjukkan adanya peningkatan yang tajam mengenai publikasi jurnal dengan topik pembelajaran daring (online). Baru-baru akhir ini, pembelajaran daring (online) menjadi banyak perhatian dari para pendidik dan para peneliti yang dikarenakan sebagai salah satu alternatif solusi pada masa pandemi Covid-19.

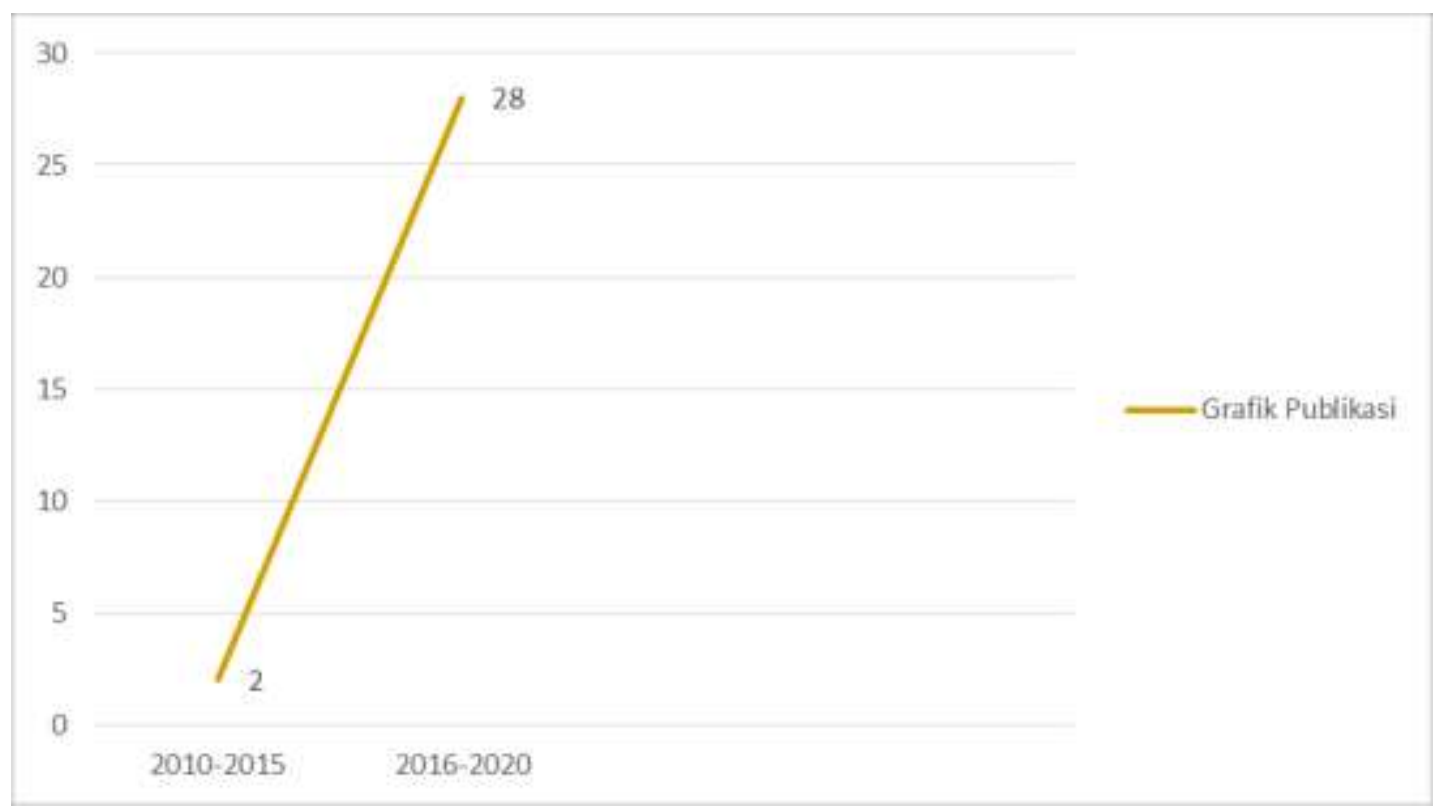

Gambar 1. Distribusi Publikasi 10 Tahun Terakhir 
Sebagian besar desain penelitian pada deskriptif $(0.67 \%)$, studi kasus $(0.1 \%)$, studi literature review $(0.17 \%)$, eksperimen semu $(0.03 \%)$, pra-eksperimental $(0.03 \%)$. Kemudian, wilayah sampel penelitian sebagian besar didominasi negara Indonesia $(0.93 \%)$, kemudian Portugis $(0.03 \%)$, dan Afrika $(0.03 \%)$ Tabel 2 menyajikan informasi deskriptif secara ringkas mengenai indikator dari publikasi jurnal.

Tabel 2. Skema Publikasi Penelitian

\begin{tabular}{|c|c|c|c|c|}
\hline Dimensi & Sub-Dimensi & Skema & 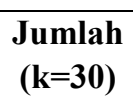 & $\begin{array}{c}\text { Proporsi } \\
(\%)\end{array}$ \\
\hline \multirow[t]{7}{*}{ Subjek } & Tingkat Sampel & (1) Sekolah Dasar & 3 & 0.1 \\
\hline & & (2) SMP dan SMA & 10 & 0.33 \\
\hline & & (3) Perguruan Tinggi & 7 & 0.23 \\
\hline & & (4) Lain-lain (umum) & 10 & 0.33 \\
\hline & Ukuran Sampel & (1) $1-30$; & 5 & 0.17 \\
\hline & & (2) 30-60; & 2 & 0.07 \\
\hline & & (3) Lebih dari 60 & 23 & 0.77 \\
\hline \multirow[t]{13}{*}{ Aturan } & Desain Penelitian & (1) Studi Kasus & 3 & 0.1 \\
\hline & & (2) Studi Literatur Review & 5 & 0.17 \\
\hline & & (3) Eksperimen Semu & 1 & 0.03 \\
\hline & & (4) Pra-Eksperimental & 1 & 0.03 \\
\hline & & (5) Deskriptif & & \\
\hline & & & 20 & 0.67 \\
\hline & Durasi Intervensi & (1) Singkat ( $<4$ minggu) & 2 & 0.07 \\
\hline & & (2) Pendek (5-16 minggu) & & \\
\hline & & (3) Menengah (17-24 minggu) & 3 & 0.1 \\
\hline & & (4) Panjang (> 24 minggu) & & \\
\hline & & (5) Tidak ditentukan & 1 & 0.03 \\
\hline & & & 1 & 0.03 \\
\hline & & & 23 & 0.77 \\
\hline \multirow[t]{3}{*}{ Konteks } & Wilayah Sampel & (1) Indonesia; & 28 & 0.93 \\
\hline & & (2) Portugis & 1 & 0.03 \\
\hline & & (3) Afrika & 1 & 0.03 \\
\hline \multirow[t]{3}{*}{ Alat } & Alat & (1) Platform pembelajaran online (daring) & 27 & 0.9 \\
\hline & pembelajaran & (2) Lain-Lain & & \\
\hline & & & 3 & 0.1 \\
\hline \multirow[t]{2}{*}{ Terbit } & Tahun Terbit & (1) $2010-2015$ & 2 & 0.07 \\
\hline & & (2) $2016-2020$ & 28 & 0.93 \\
\hline
\end{tabular}

\section{PEMBAHASAN}

\section{Konsep Kelas Digital dalam Pembelajaran Daring}

Kelas digital (digital class) merupakan suatu sistem pembelajaran tanpa interaksi secara langsung antara siswa dan guru. Sejalan dengan pendapat tersebut fokus dari pembelajaran kelas digital ini terletak pada metode pembelajaran dengan memanfaatkan fasilitas teknologi dengan mengirimkan berbagai materi, penugasan, ujian, dan penilaian secara daring sehingga memungkinkan untuk tidak bertatap muka secara langsung. Penilaian siswa yang ditujukan untuk orang tua bisa dilaksanakan secara daring melalui web learning di institusi pendidikan. Sehubungan dengan hal itu, kelas digital dilaksanakan tanpa interaksi secara langsung dengan guru dan siswa, interaksi dilakukan secara virtual dengan menggunakan bantuan teknologi.

Kelas digital yang efektif sangat diperlukan dalam keberhasilan tujuan pembelajaran. Dalam indikator pembelajaran kelas digital yang efektif ditandai dengan adanya peran aktif siswa dalam 
pembelajaran. Terciptanya suatu kelas digital yang efektif, terdapat proses pembelajaran yang kondusif serta pengelolaan kelas digital dengan baik (Purnomo \& Mansir, 2020). Dalam pelaksanaan pembelajaran kelas digital membutuhkan komunikasi yang baik antara siswa, orang tua, dan guru yang disebabkan oleh jarak yang jauh dan tidak memungkinkan untuk tatap muka sehingga dapat dilakukan secara virtual atau dunia maya (Sari et al., 2020)

Dalam pandemi Covid-19, kelas digital dilakukan sebagai salah satu ikhtiar untuk pencegahan penyebaran Covid-19. Pada protokol kesehatan untuk pencegahan penyebaran Covid19, masyarakat diminta untuk menghentikan sementara kegiatan yang memicu kerumunan massa (Firman \& Rahayu, 2020) sehingga dapat menekan penyebaran Covid-19. Dalam konteks pembelajaran, interaksi secara langsung dalam satu lingkungan sehingga memicu pengumpulan massa atau orang bisa saja berpotensi menjadi penyebab penyebaran Covid-19 meskipun dalam suatu lingkungan persekolahan maupun institusi pendidikan. Oleh karena itu, pembelajaran kelas digital sebagai salah satu bentuk ikhtiar untuk mencegah penyebaran Covid-19.

Menurut Huang et al., (2020) menyatakan bahwa selama pandemi Covid-19, proses pembelajaran dilaksanakan dengan sistem "Flexible Learning" dengan memiliki beberapa kriteria yaitu 1) Aspek pembelajaran dapat dilaksanakan bebas baik waktu maupun tempat, 2) Pembelajar (siswa) dapat belajar dari yang diinginkan, 3) Sumber belajar dapat bersumber dari pengajar (guru) secara langsung atau dengan menggunakan berbagai sumber yang telah tersedia dalam Learning System Management maupun video conference, 4) Pengajar (guru) mempunyai banyak keleluasaan dalam menentukan pelaksanaan pembelajaran, 5) Dalam implementasi penilaian dapat menggunakan system yang menyediakan keluwesan bagi siswa dalam melaporkan setiap kegiatan yang dilaksanakan selama masa pandemi Covid-19.

\section{Faktor Penentu Keberhasilan Kelas Digital di Tengah Pandemi Covid-19}

Dalam pelaksanaan kelas digital, pentingnya dalam mencermati faktor yang dapat mendorong dan mendukung pelaksanaan kelas digital dalam pembelajaran. Faktor yang menentukan keberhasilan dalam kelas digital terletak pada 3 pokok penting yaitu pengajar (guru), pembelajar (siswa, mahasiswa), dan teknologi. Dalam pembelajaran kelas digital, pengajar (guru) memiliki pengetahuan dan keterampilan dalam pembuatan media demi menunjangnya proses pembelajaran, selain itu menurut Latip (2020) pengajar (guru) memiliki kreativitas dan pengalaman dalam interaksi virtual dengan pembelajar (siswa dan mahasiswa. Sementara itu, faktor pembelajar memiliki peran penting dalam terselenggaranya proses pembelajaran. Faktor teknologi, mempunyai peranan sangat penting dalam interaksi virtual dalam proses pembelajaran antara guru dan siswa

Menurut Huang et al., (2020) menyatakan bahwa terdapat lima faktor utama yang mendorong keberhasilan pembelajaran kelas digital, yaitu 1) Manajemen institusi, 2) Lingkungan belajar, 3) Desain pembelajaran, 4) Layanan pendukung, dan 5) Evaluasi pembelajaran. Faktor manajemen institusi berkaitan pada desain perancangan pembelajaran yang dirancang oleh pusat pendidikan sampai dengan sekolah sebagai pelaksanaan di lapangan. Kurikulum yang tepat dan sesuai dengan pembelajaran akan menunjang pembelajaran sehingga dapat berjalan sesuai dengan harapan.

Faktor lingkungan belajar dalam pelaksanaan pembelajaran kelas digital di tengah pandemi Covid-19 berkaitan mengenai pelaksanaan proses pembelajaran antara guru dan siswa, kemampuan mengakses koneksi internet, dan eksistensi dari sistem online guna menunjangnya proses pembelajaran. Dalam pelaksanaan proses pembelajaran, selain memberikan materi pembelajaran, guru dapat memberikan motivasi pada siswa dikarenakan merupakan suatu hal yang 
sangat penting baik dari fisik maupun psikologis siswa (Pujiasih, 2020). Faktor lingkungan merupakan faktor yang esensial dalam pelaksanaan kelas digital di Indonesia, hal ini disebabkan ketersediaannya akses internet di Indonesia yang belum menyebar secara merata di Indonesia. Untuk mengantisipasi hal tersebut, maka Kemendikbud membuat program belajar selama dirumah (Study From Home) pada saluran TVRI yang bisa diakses seluruh penjuru di Indonesia.

Faktor yang mendukung keberhasilan pelaksanaan kelas digital di tengah pandemi Covid-19 adalah desain pembelajaran. Desain pembelajaran mendapat perhatian yang penting demi terselenggaranya proses pembelajaran. Dalam desain pembelajaran merupakan bagian esensial yang harus dikembangkan oleh guru. Metode pembelajaran kelas digital ini merupakan hal yang baru bagi sebagian guru dan siswa sehingga jika desain pembelajaran tidak dirancang dengan baik maka proses pembelajaran juga tidak sesuai dengan harapan. Desain pembelajaran meliputi beberapa komponen yaitu kejelasan tujuan pembelajaran, strategi pembelajaran, kualitas konten pembelajaran dan penilaian pembelajaran. untuk keberhasilan dalam proses pembelajaran dengan memperhatikan komponen-komponen tersebut.

Faktor yang pendukung lainnya dalam keberhasilan pelaksanaan kelas digital di tengah pandemi Covid-19 adalah layanan pendukung. Pelayanan pendukung kelas digital yaitu pelatihan. Dalam konteks pandemi Covid-19, hanya sebagian kecil sekolah yang mengadakan pelatihan terencana dalam pelaksanaan proses pembelajaran kelas digital. Pelaksanaan pelayanan kelas digital menjadi hal penting dalam proses pembelajaran guna meningkatkan kemampuan guru dan siswa dalam mengelola teknologi pembelajaran kelas digital.

Faktor terakhir dalam mendukung keberhasilan pelaksanaan kelas digital di tengah pandemi Covid adalah evaluasi pembelajaran. evaluasi pembelajaran merupakan bagian yang esensial setelah terlaksananya proses pembelajaran. namun, dalam melakukan evaluasi pembelajaran berlangsung secara fleksibel seperti presentasi, maka penelitian yang membahas isu-isu yang berkaitan dengan pandemi Covid-19. Evaluasi pembelajaran menganut pada prinsip-prinsip yang telah ditetapkan yaitu kontinuitas, komprehensif, adil dan objektif, kooperatif, serta praktis (Fitrianti, 2018). Metode penilaian dapat berupa quiz, tes online yang sudah dilaksanakan sebagian besar pengajar.

\section{Kelas Digital dalam Pelaksanaan Pembelajaran Daring}

Kelas Digital merupakan salah satu bagian penting dalam pelaksanaan proses pembelajaran daring, kelas digital juga sebagai media interaksi proses pembelajaran dengan berbantuan teknologi pada pembelajaran daring. Sementara itu, kelas digital juga membantu guru dalam pembelajaran seperti melakukan peninjauan (pengawasan) pembelajaran, evaluasi proses pembelajaran, serta bisa berdiskusi mengenai pembelajaran yang terhalang oleh jarak. Peninjauan (pengawasan) pembelajaran dapat berupa pemberian motivasi kepada siswa baik secara fisik maupun psikis. Evaluasi proses pembelajaran merupakan bagian akhir setelah proses pembelajaran itu terjadi. Evaluasi juga sebagai patokan dalam proses pembelajaran apakah peserta didik sudah menguasai materi atau belum. Aktivitas evaluasi dapat dikatakan efektif jika evaluasi tersebut dilakukan berdasarkan prinsip-prinsip yang telah ditetapkan yaitu kotinuitas, komprehensif, adil dan objektif, kooperatif, serta praktis (Fitrianti, 2018). Sehubungan dengan hal itu, kelas digital mempunyai peranan penting dalam proses pembelajaran.

Pembelajaran daring merupakan suatu pembelajaran tanpa membatasi jarak dan waktu dengan bantuan platform digital yang menggunakan akses internet sehingga mendukung proses pembelajaran tanpa adanya interaksi secara fisik (Putra \& Irwansyah, 2020)

Terdapat lima tolok ukur dalam penerapan kelas digital yaitu 1) mempersiapkan kemudahan 
dalam akses sumber daya terhadap proses pembelajaran, 2) menampilkan kesamaan antara kelas konvensional (tatap muka) dengan kelas virtual (daring), 3) menghadirkan proses pembelajaran efektif baik berbasis Learning Management System (LMS) maupun video conference, 4) memfasilitasi semua pengguna tanpa terbatas pada pengalaman dalam penggunaan teknologi, 5) mampu memfasilitasi interaksi virtual antara guru dan siswa, terkhusus pada diskusi baik berupa pertanyaan, atau tanggapan.

Dari penerapan 5 esensial, maka proses pembelajaran daring perlu dirancang sedemikian rupa dengan baik dan memperhatikan dari berbagai dimensi. Dimensi yang berkaitan dengan teknologi dan penggunanya yang meliputi pengajar, pembelajar dan yang lainnya. Jika kemampuan dalam penggunaan teknologi masih dibawah standar, maka mau seberapa canggihnya teknologi yang tersedia, tidak akan bisa mendukung berlangsungnya proses pembelajaran daring.

\section{Model Kelas Digital untuk Membimbing siswa}

Diperlukan adanya model untuk membimbing siswa dalam pembelajaran di tengah pandemi Covid-19. Model pembelajaran perlu dirancang dengan baik agar pengalaman belajar peserta didik berkesan dan dapat mencapai tujuan pembelajaran (Yanti et al., 2020). Kemendikbud telah bekerja sama dengan berbagai pihak yang mengembangkan sistem pendidikan Learning System Management dan Video conference. Setiap platform Learning Management System seperti Google Indonesia, Kelas Pintar, Microsoft, Quipper, Ruang Guru, Sekolahmu, dan Zenius serta Portal Rumah Belajar yang dapat diakses secara gratis dan bersifat umum. Sementara itu, Video Conference bisa berupa Zoom, Visco Webex. Masih banyak lagi, LMS dan Video Conference yang digunakan di kalangan institusi pendidikan, namun penulis hanya memberikan contoh platform yang digunakan sebagian besar kalangan masyarakat di Indonesia. Oleh karena itu, dengan adanya platform-flatform tersebut proses pembelajaran seharusnya dapat berjalan dengan tujuan yang akan dicapai dan sesuai dengan harapan.

1. Google Indonesia

Google Indonesia bersedia untuk membantu meningkatkan pembelajaran yang bersifat umum dan diakses secara gratis melalui G Suite for Education. Menurut Ardiyanto dalam blog kemendikbud, dengan menggunakan G Suite for Education, para siswa akan belajar meskipun dalam akses internetnya lelet atau tidak tersedia dan dapat diakses secara bebas artinya dapat diakses dimanapun (Kemdikbud, 2020). Sekolah dapat menggunakan Google Hangouts Meet guna untuk kepentingan meeting atau rapat antar pihak sekolah, alat konferensi video yang tersedia untuk pengguna G Suite, dan Google Classroom untuk pembelajaran jarak jauh atau daring selama proses pembelajaran di tengah pandemi Covid-19. Google Classroom ini juga bertujuan untuk mengatur kegiatan kelas seperti pembentukan kelas, pemberian materi, pemberian tugas, pemberian nilai yang dilakukan dalam satu tempat dengan efisien.

2. Kelas Pintar

Kelas pintar adalah salah satu solusi belajar di tengah pandemi Covid-19 yang dirancang untuk meningkatkan minat belajar dan wawasan siswa guna mendapat nilai akademis yang lebih baik. Dalam platform ini, dengan kelebihan pada sarana belajar tanpa melenyapkan interaksi (komunikasi) antara siswa dengan gurunya mengenai perkembangan proses pembelajarannya. Terdapat fitur baru yang diberi nama "Sekolah" bertujuan untuk menguatkan peran sekolah, guru dan siswa dalam proses pembelajaran sehingga dapat mengintegrasikan ekosistem pendidikan di platform digital tanpa menyampingkan peran stakeholder.

3. Microsoft

PT. Microsoft Indonesia mengatakan pihaknya memfasilitasi akses Office 365 untuk 
pendidikan. Dengan penggunaan layanan ini, pihak sekolah hanya perlu membekali ranah institusi sebagai jati diri digital para guru dan siswa. Dalam fasilitas Teams Office 365, proses pembelajaran dapat berlangsung secara digital dan guru dapat bertatap muka dengan murid melalui fasilitas video konferensi jika diperlukan. Guru dapat memberikan bahan ajar secara daring, suara, ataupun video melalui teams class terhadap siswanya. Begitu sebaliknya para murid dapat diskusi melalui teams class tersebut.

\section{Quipper}

Quipper School yang digunakan dalam pembelajaran dapat menumbuhkan motivasi belajar siswa karena dalam platform ini menyelenggarakan kegiatan pembelajaran menjadi lebih menarik dan memiliki fitur-fitur utama dalam pembelajaran tanpa harus bertatap muka secara langsung (face to face) (Trisnaningsih et al., 2016). Dengan menggunakan quipper guru dapat mengatur materi pembelajaran, ujian, dan nilai siswa. Menurut Kusuma (dalam Surahmadi, 2016), Quipper School mengombinasikan dan mengkonsolidasikan guru dengan siswa secara online (virtual learning), menambah wawasan pengetahuan siswa serta meningkatkan minat belajar siswa. Dalam pandemi covid-19 ini, salah satu yang diperlukan siswa adalah bagaimana untuk meningkatkan belajar siswa yang pada mulanya dapat belajar secara tatap muka, kini harus diganti dengan pembelajaran jarak jauh.

5. Ruang Guru

Ruang guru merupakan sebuah media yang menghubungkan pelajar dengan pengajar (Rahadian et al., 2019). Dimana siswa dapat mencari guru berdasarkan kebutuhannya dan begitu pula guru dapat mengajarkan ilmunya. Ruang guru menyediakan sistem kelola pembelajaran secara virtual. Dari ruang guru tersebut, guru juga mendapat pelatihan gratis yang sebanyak 250 modul. Ruang Guru meluaskan berbagai layanan belajar berdasar teknologi termasuk layanan kelas online (jarak jauh), ujian online, video belajar, serta edukasi yang bisa diakses melalui web ataupun aplikasi Ruang Guru (Komalasari, 2016).

Ruang Guru sebagai perusahaan lokal berkomitmen untuk bekerjasama dengan pemerintah daerah guna meningkatkan nilai akademis dan meningkatkan minat belajar siswa di seluruh Indonesia dengan teknologi (Rahmadani, N. S., \& Setiawati, M., 2019). Ruang guru juga menyediakan beberapa fasilitas yang dapat diakses secara gratis melalui laman youtube Ruang Guru.

6. Sekolahmu

Untuk memfasilitasi proses pembelajaran dari rumah, platform sekolahmu menyampaikan ketersediaannya untuk berdedikasi dalam pengadaan program belajar berbasis digital yang dapat diakses secara gratis bagi siswa, guru, dan orangtua di setiap jenjang pendidikan di Indonesia. Selain memfasilitasi program belajar online, sekolahmu juga memfasilitasi edukasi mengenai Covid-19. Sekolahmu juga menyediakan kelas home learning bagi semua jenjang sebagai kegiatan belajar di rumah yang disebabkan oleh Covid-19.

7. Zenius

Platform zenius juga diakses secara gratis dan bersifat umum. Salah satu faktor penting dalam menyokong keberhasilan dalam proses pembelajaran yaitu interaksi antara guru dan siswa. Karenanya, kelas online Zenius juga dilengkapi dengan fitur Live Chat, sehingga siswa dapat berkomunikasi dan memberikan pertanyaan atau pendapat kepada tutor saat proses pengajaran berjalan (Komalasari, 2016). Zenius juga berusaha untuk menerapkan proses pembelajaran yang efektif. Hal ini sesuai dengan pendapat Abidah, et al., 2020 yang menyatakan "if previously learning independently was considered not directed and measurable, Zenius also 
formulated ways to help children learn independently at home that were effective and efficient, directed and measurable" (Abidah et al., 2020). Dari pendapat tersebut menyatakan jika sebelumnya belajar secara sendiri dianggap tidak teratur dan ternilai, zenius juga menyusun cara untuk membantu siswa dalam belajar sendiri yang efektif, efisien, dan ternilai.

8. Portal Rumah Belajar

Portal Rumah Belajar merupakan sebuah inovasi Kemendikbud demi tercapainya tujuan dari revolusi 4.0. Portal Rumah Belajar adalah sebuah platform belajar yang memfasilitasi aturan tata kelola pembelajaran yang bisa diterapkan guru dan siswa dalam mengelola aktivitas pembelajaran di kelas secara virtual (Yanti et al., 2020). Dengan adanya Portal Rumah Belajar, diharapkan siswa dan guru melek mengenai perkembangan teknologi. Menurut Yudiastuti \& Megawaty, (2015) Rumah Belajar berfungsi sebagai 1) wahana komunikasi antar sekolah; 2) sebagai media untuk sumber belajar guna mendalami materi pembelajaran; 3) wahana memberi informasi antar sekolah di Indonesia. Rumah Belajar ini melonggarkan guru dalam membuat pembelajaran yang menarik, terdapat materi yang bisa diakses dari portal tersebut. Rumah Belajar ini juga merupakan salah satu platform yang memfasilitasi teknologi dalam pembelajaran daring.

\section{Zoom}

Zoom merupakan sebuah video coference yang mana dapat mempresentasikan materi dengan menggunakan screen share sehingga dapat menunjang proses pembelajaran. Zoom menyediakan fasilitas videotelephony dan chat online melalui platform peer-to-peer yang mendasar cloud dan dipakai untuk telekonferensi, telekomunikasi, pendidikan jarak jauh (daring), dan hubungan social..

10. Visco Webex

Visco Webex juga merupakan sebuah video conference yang mirip dengan zoom sehingga juga dapat mempresentasikan screen share demi terselenggaranya proses pembelajaran. Visco Webex dapat digunakan sebagai video referencing, meeting online, screen share, dan webinars.

Dari platform-platform yang telah diuraikan diatas, maka guru seharusnya dapat membimbing siswa dalam proses pembelajaran secara efektif. Sebagian besar platform didukung seperti video sehingga guru dapat menjelaskan materi seperti pembelajaran pada umumnya yang telah diterapkan di sekolah. Siswa menjadi lebih mudah mencerna materi yang dijelaskan melalui video tersebut. Sehingga seharusnya pembelajaran dapat terlaksana sesuai dengan tujuan yang akan digapai dalam pembelajaran daring.

Jika memiliki kemampuan penggunaan teknologi di bawah standar, maka secanggih apapun teknologi tidak akan bisa mendukung keberlangsungan proses pembelajaran secara daring. Oleh karena itu, pembiasaan dan pembudayaan menjadi bagian penting dalam melangsungkan proses pembelajaran.

\section{Pembiasaan Kelas Digital untuk Membimbing Siswa Dalam Pembelajaran di Tengah Pandemi Covid-19}

Menurut Teori Pavlov, pembiasaan merupakan suatu sikap yang berupa reaksi respon dan adanya stimulus yang berulang-ulang. Pembiasaan merupakan salah satu pendidikan karakter. Menurut Muhamin (Hidayat, 2016), kebiasaan ini biasanya dilakukan secara turun temurun dari orang tua ke anak, guru ke murid. Kebiasaan memegang peranan penting dalam kehidupan manusia karena sudah menjadi kebiasaan yang menyatu dan dipergunakan untuk kegiatan di lapangan (Supiana \& Sugiharto, 2017). Pembiasaan awalnya bersifat mekanistik yang diusahakan 
siswa secara mandiri dilakukan secara berangsur-angsur disertai dengan penjelasan-penjelasan dan nasihat-nasihat.

Pembiasaan kelas digital adalah suatu reaksi respon dengan stimulus yang berulang-ulang dengan menerapkan penggunaan teknologi sehingga yang pada awalnya menggunakan pembelajaran konvensional menjadi pembelajaran jarak jauh (daring). Pembiasaan kelas digital ini memiliki peran penting salah satunya dalam pemberian layanan dari guru ke siswa maupun sebaliknya tanpa bertatap muka secara langsung. Pemberian layanan dapat berupa diskusi mengenai materi yang diajarkan, penugasan, pelayanan mengenai sekolah karena pandemi Covid19 yang dapat dilakukan secara daring (online) tanpa harus bertatap muka.

Sehubungan dengan adanya pandemi Covid-19, maka Kemendikbud menyarankan belajar dari rumah atau pembelajaran daring. Sehingga guru dan siswa dituntut harus dapat membangun dan membiasakan kelas digital sebagai perubahan pembelajaran yang konvensional. Dalam membiasakan kelas digital ini dimulai dari hal yang utama terlebih dahulu yaitu pertama, membangun kelas agar siswa bersemangat dalam melakukan proses pembelajaran. Yang kedua, siswa diberi informasi mengenai kelas digital ini yang terdapat beberapa platform, baik yang sudah tersedia maupun dari institusi pendidikan. Yang ketiga, guru menggunakan salah satu platform yang dipandang efektif saja agar pembelajaran dapat berjalan dengan baik. Penugasan memang dipandang efektif dalam pembelajaran daring namun untuk pemahaman konsep dari materi itu tidak berhasil efektif. Maka perlu diadakannya pembiasaan kelas digital ini guna membimbing siswa dalam proses pembelajarannya agar berjalan dengan efektif dan sesuai dengan tujuan pembelajaran yang akan digapai.

\section{Pembudayaan Kelas Digital Untuk Membimbing Kelas Digital Dalam Pembelajaran di Tengah Pandemi Covid-19}

Pembudayaan adalah suatu proses atau cara hasil kegiatan dan penciptaan batin (akal budi) yang mana menjadi suatu adat kebiasaan yang turun temurun. Menurut Adi (dalam E.B Tylor, 1971), menyatakan bahwa pembiasaan merupakan suatu proses yang kompleks yang memuat pengetahuan, kepercayaan, kesenian, moral, hukum, adat istiadat, kemampuan, serta kebiasaan dari penduduk tersebut. Suatu proses pembudayaan dibedakan berdasarkan wujudnya (Adi, 2016) yaitu 1) Sebagai gagasan, nilai, norma dan peraturan; 2) Sebagai kegiatan serta reaksi teratur dari manusia ke masyarakat; 3) Sebagai benda-benda buatan manusia.

Dalam konteksnya, pembiasaan itu sama dengan pembudayaan. Pembiasaan dan pembudayaan memiliki hubungan yang erat. Pembiasaan itu terletak pada kebiasaan yang harus diterapkan sedangkan pembudayaan merupakan suatu pembiasaan yang mempunyai nilai budaya. Apabila pembiasaan dapat diterapkan dengan baik, maka pembudayaan juga akan berjalan dengan baik. Namun dalam pembudayaan ini menghasilkan sesuatu yang berlandaskan cipta, rasa dan karsa. Dalam kelas digital ini, pembudayaan sangat berpengaruh pada siswa sehingga siswa dapat membentuk nilai-nilai yang ada pada diri siswa sehingga menimbulkan rasa kebiasaan dalam membudayakan kelas digital ini.

Pembudayaan kelas digital merupakan suatu pembiasaan yang menghasilkan pengetahuan dan keterampilan yang diperoleh melalui proses pembelajaran dengan menerapkan penggunaan teknologi yang mana pada awalnya dalam proses pembelajaran menerapkan pembelajaran konvensional. Pembelajaran konvensional seperti mengajar di sekolah seperti biasanya dengan menggunakan literasi lama seperti membaca, menghitung, menulis dan sebagainya.

Pembudayaan kelas digital di tengah pandemi Covid-19 dalam membimbing siswa selama proses pembelajaran jarak jauh seharusnya dapat berjalan dengan baik dan efektif. Karena 
sebelumnya, siswa terlebih dahulu beradaptasi dengan diberikan sosialisasi mengenai seperti apa kelas digital demi menunjangnya proses pembelajaran sehingga siswa tidak terombang-ambing mengenai kelas digital yang disebabkan karena informasi dari luar yang membuat siswa kebingungan. Setelah melalui pembiasaan pengenalan kelas digital, maka siswa kemudian akan mengalami proses pembelajaran kelas digital yang mana kelas digital ini memanfaatkan teknologi dan akses internet dengan guru melakukan proses pembelajaran secara daring yang meliputi pemberian materi online, penugasan secara online, dan ujian secara online. Guru dapat menggunakan platform-platform yang telah tersedia baik yang bekerjasama dengan Kemendikbud maupun dari institusi pendidikan itu sendiri yang dianggap mumpuni sesuai dengan kriteria masing-masing platform. Pembiasaan itu berulang-ulang secara terus menerus sehingga menjadi budaya dalam proses pembelajaran.

Sehubungan dengan wabah Covid-19 ini, maka sesuai dengan anjuran pemerintah yaitu Work From Home maka seorang guru tetap melaksanakan tugasnya sebagaimana mestinya dengan tidak meninggalkan identitasnya sebagai seorang guru guna mengajarkan ilmunya kepada siswa. Keorisinilan kelas digital ini harusnya lebih efektif daripada kelas konvensional yang sebelumnya yang menerapkan literasi lama. Dengan penggunaan kelas digital ini guru tidak membuang tenaga yang jauh lebih besar dari biasanya. Namun, dalam kelas digital ini memang diperlukan kekreatifan guru dalam melaksanakan proses pembelajaran daring sehingga proses pembelajaran dapat berlangsung dengan baik.

\section{SIMPULAN}

Berdasarkan uraian hasil dan pembahasan, kelas digital merupakan suatu kelas yang menerapkan penggunaan teknologi (digital) sebagai pembelajaran jarak jauh atau pembelajaran daring. Model dalam kelas digital termuat beberapa platform yang mewadahi pembelajaran agar pembelajaran dapat berjalan dengan efektif. Platform-platform tersebut seperti Google Indonesia, Microsoft, Ruang Guru, Sekolahku, Kelas Pintar, Quipper, dan Zenius serta Rumah Belajar yang diresmikan oleh Kemendikbud dalam website Kemendikbud. Pembudayaan merupakan suatu pembiasaan yang memiliki nilai budaya yang bermanfaat bagi dirinya sendiri dan orang lain. Apabila pembiasaan dapat berjalan dengan baik, maka pembudayaan juga berjalan dengan baik. Pembudayaan kelas digital merupakan suatu pembiasaan yang memiliki budaya dengan menerapkan penggunaan teknologi sebagai pembelajaran jarak jauh atau daring yang mana awalnya menerapkan proses pembelajaran konvensional. Dalam penerapan pembelajaran kelas digital

Dalam penerapan kelas digital apabila pengajar (guru) dan pembelajar (siswa) memiliki kemampuan dibawah mumpuni atau di bawah standar, maka mau secanggih apapun teknologi tidak akan dapat melangsungkan proses pembelajaran daring. Pembudayaan merupakan suatu pembiasaan yang memiliki nilai budaya yang harus diterapkan pada siswa.

\section{UCAPAN TERIMA KASIH}

Pada kesempatan yang berbahagia kali ini, penulis mengucapkan banyak terimakasih kepada beberapa pihak yang telah membantu menyusun artikel ini. Terutama ditujukan pada dosen pengampu mata kuliah Penelitian Pendidikan Matematika yang telah memberikan kesempatan untuk menyusun artikel ini sehingga terlaksananya dalam penulisan artikel ini. Serta kepada teman-teman Prodi Pendidikan Matematika angkatan 2017 yang telah membantu menyusun artikel ini. 


\section{DAFTAR RUJUKAN}

Abidah, A., Hidaayatullah, H. N., Simamora, R. M., Fehabutar, D., \& Mutakinati, L. (2020). The Impact of Covid-19 to Indonesian Education and Its Relation to the Philosophy of "Merdeka Belajar ." Studies in Philosophy of Science and Education, 1(1), 38-49.

Adi, P. (2016). Pembudayaan Nilai-nilai Pancasila Bagi Masyarakat Sebagai Modal Dasar Pertahanan Nasional NKRI. Jurnal Moral Kemasyarakatan, 1(1), 37-50.

Almeida, F., \& Simoes, J. (2019). The role of serious games, gamification and industry 4.0 tools in the education 4.0 paradigm. Contemporary Educational Technology, 10(2), 120-136.

Ashari, M. (2020). Proses Pembelajaran Daring di Tengah Antisipasi Penyebaran Virus Corona Dinilai Belum Maksimal. (Online). Diakses 12 Juni 2020 dari : https://www.pikiranrakyat.com/pendidikan/pr-01353818/proses-pembejalaran-daring-di-tengah-antisipasi-penyebaranvirus-corona-dinilai-belum-maksimal

Astini, N. K. S. (2020). Tantangan Dan Peluang Pemanfaatan Teknologi Informasi Dalam Pembelajaran Online Masa Covid-19. Cetta: Jurnal Ilmu Pendidikan, 3(2), 241-255.

Effendi, H., \& Dwiyani, N. (2018). Learning Management System Berbasis Cloud Sebagai Alternatif Pembelajaran Bagi Guru Sekolah Menengah Pertama. Jurnal Teknologi Informasi dan Pendidikan. $11(2), 80-84$.

Firman, F., \& Rahayu, S. (2020). Pembelajaran Online di Tengah Pandemi Covid-19. Indonesian Journal of Educational Science (IJES), 2(2), 81-89.

Fitrianti, L. (2018). Prinsip Kontinuitas dalam Evaluasi Proses Pembelajaran. AL-ISHLAH: Jurnal Pendidikan, 10(1), 89-102.

Fitriyani, Y., Fauzi, I., \& Sari, M. Z. (2020). Motivasi Belajar Mahasiswa Pada Pembelajaran Daring Selama Pandemik Covid-19. Jurnal Kependidikan: Jurnal Hasil Penelitian dan Kajian Pustaka di Bidang Pendidikan, Pengajaran, dan Pembelajaran 6(2), 165-175.

Fomunyam, K. G. (2019). Education and the Fourth Industrial Revolution: Challenges and Possibilities for Engineering. International Journal of Mechanical Engineering and Technology (IJMET), 10(08), 271284.

Handayani, L. (2020). Peningkatan Motivasi Belajar IPA Melalui Model Pembelajaran Project Based Learning pada Masa Pandemi Covid-19 bagi Siswa SMP Negeri 4 Gunung Sari. Jurnal Paedagogy: Jurnal Penelitian Dan Pengembangan Pendidikan, 7(3), 168-174.

Handayani, L. (2020). Keuntungan, Kendala dan Solusi Pembelajaran Online Selama Pandemi Covid-19: Studi Ekploratif di SMPN 3 Bae Kudus. JIEMAR: Journal Industrial Engineering and Management Research, 1(2), 15-23

Hartanto, A. D., \& Nurharjanti, M. (2018, 27 September). Implementasi Teknologi Pembelajaran dan Kelas Digital Untuk SMP Kota Yogyakarta. Prosiding Seminar Nasional seri 8 " Mewujudkan Masyarakat Madani dan Lestari ". Diseminasi Hasil-Hasil Pengabdian Universitas AMIKOM Yogyakarta. September, 58-65.

Hidayat, N. (2016). Implementasi Pendidikan Karakter Melalui Pembiasaan di Pondok Pesantren Pabelan. Jurnal Pendidikan Sekolah Dasar, 2(1), 128-145.

Huang, R. H., Liu, D. J., Tlili, A., Yang, J. F., \& Wang, H. H. (2020). Handbook on facilitating flexible learning during educational disruption: The Chinese experience in maintaining undisrupted learning in COVID-19 Outbreak. In Smart Learning Institute of Beijing Normal University UNESCO. https://iite.unesco.org/news/handbook-on-facilitating-flexible-learning-during-educational-disruption/

Husaini, M. (2014). Pemanfaatan Teknologi Informasi Dalam Bidang Pendidikan (E-Education). Jurnal Mikrotik, 2(1), 1-5.

Ichsan, I. Z., Rahmayanti, H., Purwanto, A., Sigit, D. V., Kurniawan, E., Dewi, A. K., Wirdianti, N., Hermawati, F. M., \& Marhento, G. (2020). PEMBELAJARAN SAINS DAN LINGKUNGAN DI SMP. JINoP: Jurnal Inovasi Pembelajaran, 6(1), 50-61.

Indrayana, B., \& Sadikin, A. (2020). Penerapan E-Learning Di Era Revolusi Industri 4 . 0 Untuk Menekan Penyebaran. Indonesion Journal of Sport Science and Coaching, 1(1), 46-55.

Kemendikbud. (2020). Cegah Sebaran Covid-19 di Satuan Pendidikan, Kemendikbud Gandeng Swasta Siapkan Solusi Belajar Daring. (Online). Diakses dari: https://www.kemdikbud.go.id/main/blog/2020/03/cegah-sebaran-covid19-di-satuan-pendidikankemendikbud-gandeng-swasta-siapkan-solusi-belajar-darin

Komalasari, R. (2016). Manfaat Teknologi Informasi dan Komunikasi di Masa Pandemi Covid-19. Tematik- 
Jurnal Teknologi Informasi Dan Komunikasi, 3(1), 86-99.

Latip, A. (2020). Peran Literasi Teknologi Informasi Dan Komunikasi Pada Pembelajaran Jarak Jauh Di Masa Pandemi Covid-19. EduTeach : Jurnal Edukasi Dan Teknologi Pembelajaran, 1(2), 108116.

Nurani, N. I., Uswatun, D. A., \& Maula, L. H. (2020). Analisis Proses Pembelajaran Matematika Berbasis Daring Menggunakan Aplikasi Google Classroom Pada Masa Pandemi Covid-19. Jurnal PGSD, 6(1), $50-56$

Pakpahan, R., \& Fitriani, Y. (2020). Analisa Pemanfaatan Teknologi Informasi dalam Pembelajaran Jarak Jauh di Tengah Pandemi Virus Corona Covid-19. JISAMAR ( Journal of Information System, Applied, Management, Accounting and Researh ) p-ISSN : 2598-8700, 4(2), 3036.

Pujiasih, E. (2020). Membangun Generasi Emas Dengan Variasi Pembelajaran Online Di Masa Pandemi Covid-19. Ideguru: Jurnal Karya Ilmiah Guru. 5(1), 42-48.

Purnomo, H., \& Mansir, F. (2020). Pendidikan Karakter Islami pada Online Class Management di SMA Muhammadiyah 7 Yogyakarta Selama Pandemi Covid-19. Jurnal Tarbiyatuna, 11(1), 2579-4981.

Purwanto, A., Pramono, R., Asbari, M., Santoso, P. B., Wijayanti, L. M., Choi, C. H., \& Putri, R. S. (2020). Studi Eksploratif Dampak Pandemi COVID-19 Terhadap Proses Pembelajaran Online di Sekolah Dasar. EduPsyCouns: Journal of Education, Psychology and Counseling, 2(1), 1-12.

Putra, R. S., \& Irwansyah. (2020). Media Komunikasi Digital, Efektif Namun Tidak Efisien, Studi Media Richness Theory Dalam Pembelajaran Jarak Jauh Berbasis Teknologi di Masa Pandemi. Global komunika, 1(2), 1-13.

Rachmawati, Y., Ma'arif, N., Fadillah, N., Inayah, N., Ummah, K., Siregar, M. N. F., Amalyaningsih, R., Aftannaila, H., \& Auliyah, A. (2020). Studi Eksplorasi Pembelajaran Pendidikan IPA Saat Masa Pandemi Covid-19 di UIN Sunan Ampel Surabaya. Indonesian Journal of Science Learning. 1(1), $32-$ 36.

Rahadian, D., Rahayu, G., \& Oktavia, R. R. (2019). Teknologi Pendidikan: Kajian Aplikasi Ruangguru Berdasarkan Prinsip dan Paradigma Interaksi Manusia dan Komputer. Jurnal Petik, 5(1), 11-24.

Rahmadani, N. S., \& Setiawati, M. (2019). Aplikasi Pendidikan Online "Ruang Guru" Sebagai Peningkatan Minat Belajar Generasi Milenial Dalam Menyikapi Perkembangan Revolusi Industri 4.0. Seloka: Jurnal Pendidikan Bahasa Dan Sastra Indonesia, 3(2), 241-246.

Rindiana, D., \& Firdausi, T. (2019). Evaluasi Penerapan Kelas Digital pada SMP Al-Azhar 21 Sukoharjo. Academia: Journal of Multidisciplinary Studies. 3(1), 77-92. ISSN 2579-9711

Robandi, D., Ritonga, I., Nast, T. P. J., Rusdinal., \& Gistituati, N. (2020). An Analysis of Education Policy In The Pandemic Covid-19. E-Tech: E-Journal Tech, 08(02), 1-4.

Sari, W., Rifki, A. M., \& Karmila, M. (2020). Pembelajaran Jarak Jauh Pada Masa Darurat Covid 19. Jurnal Mappesona, 2(1), 1-13.

Solviana, M. D. (2020). Pemanfaatan Teknologi Pendidikan di Masa Pandemi Covid-19: Penggunaan Fitur Gamifikasi Daring di Universitas Muhammadiyah Pringsewu Lampung. Al-Jahiz: Journal of Biology Education Research, 1(1), 1-14.

Subekti, H., Taufiq, M., Susilo, H., Ibrohim, I., \& Suwono, H. (2017). Mengembangkan Literasi Informasi Melalui Belajar Berbasis Kehidupan Terintegrasi Stem Untuk Menyiapkan Calon Guru Sains Dalam Menghadapi Era Revolusi Industri 4.0: Revieu Literatur. Education and Human Development Journal, $3(1), 81-90$.

Sudibyo, L. (2011). Peranan dan Dampak Teknologi Informasi dalam Dunia Pendidikan di Indonesia. Widyatama, 20(2), 175-185.

Supiana \& Sugiharto, R. (2017). Pembentukan Nilai-Nilai Karakter Islami Siswa Melalui Metode Pembiasaan. Jurnal Educan. 1(1), 89- 109.

Surahmadi, B. (2016). Pengaruh Media Pembelajaran Virtual Berbasis Quipper School Untuk Meningkatkan Motivasi Belajar Dan Hasil Belajar Peserta Didik Kelas Viii Smp N 1 Temanggung. USEJ - Unnes Science Education Journal, 5(1), 1123-1127.

Surat Edaran Direktorat Jenderal Pendidikan Tinggi Kemdikbud Nomor 1 Tahun 2020. Pencegahan Penyebaran Coronavirus Disease (Covid-19) Di Perguruan Tinggi. Jakarta

Surat Edaran Nomor 4 Tahun 2020. Pelaksanaan Kebijakan Pendidikan Dalam Masa Darurat Penyebaran Coronavirus Disease (Covid-19). 24 Maret 2020. Jakarta

Sutama. (2019). Metode Penelitian Pendidikan: Kuantitaif, Kualitatif, Penelitian Tindakan Kelas, Mix 
Method, $R \& D$. Cetakan 1. Gumpang: CV Jasmine.

Trisnaningsih, S., Suyanto, S., \& Rahayu, T. (2016). Pengembangan Learning Management System Quipper School pada Pembelajaran Materi Sistem Pertahanan Tubuh untuk Meningkatkan Motivasi dan Hasil Belajar Siswa Kelas XI di SMA Negeri 3 Yogyakarta. Jurnal Pendidikan Biologi, 5(6), 28-36.

Wahyudin, D. (2010). Model pembelajaran ICARE pada kurikulum mata pelajaran TIK di SMP. Jurnal Penelitian Pendidikan, 11(1), 23-33.

Yanti, M. T., Kuntarto, E., \& Kurniawan, A. R. (2020). Pemanfaatan Portal Rumah Belajar Kemendikbud Sebagai Model Pembelajaran Daring di Sekolah Dasar. Adi Widya, Jurnal Pendidikan Dasar, Institut Hindu Dharma Negeri Denpasar, 5(1), 61-68.

Yudiastuti, H., \& Megawaty, M. (2015). Mengukur Kualitas Portal Rumah Belajar Dengan Menggunakan Metode Webqual 4.0. Jurnal Ilmiah Matrik, vol17 no (2), 163-172. 